\title{
Kelola
}

\section{EVALUASI PROGRAM BUDAYA MEMBACA DI SEKOLAH DASAR NEGERI}

\author{
Andri Sulistyo \\ SMP Kristen Terang Bangsa \\ Cirebon-Jawa Barat \\ sulistyoandri23@yahoo.co.id
}

\begin{abstract}
The purpose of this study is to evaluate implementation of literacy program in Public Elementary School Tengaran (SD N Tengaran), District of Semarang. Evaluation using CIPP model. Data collection through interview, documentation, and observation with triangulation technique. The data is analyzed by description, reduction, data display and data verification. The result shows that from context aspect, students in Public Elementary School Tengaran (SD N Tengaran) need this literacy program; in input aspect, this program has answered the needs of students with support by human resources, infrastructure, budget, schedule and adequate working mechanisms; process aspect, the implementation is implemented according to plan, although there were obstacles in routine activities such as teacher's and student's low consistency as well as poor support from parents; and in product aspect, the result of literacy program is $90 \%$ of students have read fluently, $60 \%$ of students are confidence to do presentation, $66 \%$ of students are able to make bulletin board independently, $66 \%$ of students are able to write resume independently, 90\% of students actively write their personal experience in the diary, one of 65 students passed the selection to the district level in reading poetry competition, and one student passed and get third place in speech competition in subdistrict level. Based on the findings, literacy program should be continued but need improvement.
\end{abstract}

\section{Keywords: Evaluation program, literacy, CIPP model}




\section{PENDAHULUAN}

Tingkat literasi membaca di Indonesia sangatlah rendah. Berdasarkan uji literasi yang dilakukan oleh IEA tahun 2011 (data PIRLS), Indonesia menempati peringkat ke 45 dari 48 negara yang menjadi peserta dengan skor 428 (skor rata-rata semua peserta 500) (Direktorat Jenderal Pendidikan Dasar dan Menengah Kementrian Pendidikan dan Kebudayaan Tahun 2016 hal 1). Sementara itu, uji literasi membaca menurut data PISA 2009 menunjukkan peserta didik Indonesia berada pada peringkat ke 57 dengan skor 396 (skor rata-rata 493), sedangkan data PISA 2012 menunjukkan peserta didik Indonesia berada pada peringkat ke 64 dengan skor 396 dari rata-rata skor OECD 496, sebanyak 65 negara berpartisipasi dalam PISA 2009 dan 2012 (Direktorat Jenderal Pendidikan Dasar dan Menengah Kementrian Pendidikan dan Kebudayaan, 2016: 2). Berdasarkan data PISA 2015 tingkat literasi di Indonesia belum menunjukkan peningkatan yang signifikan yaitu sebesar 1 poin dari skor 396 di tahun 2012 menjadi 397 di tahun 2015. Peningkatan tersebut mengangkat posisi Indonesia 6 peringkat ke atas (peringkat 62 dari 70 peserta) bila dibandingkan posisi peringkat kedua dari bawah pada tahun 2012 (OECD, 2015). Meski terdapat peningkatan namun tingkat literasi di Indonesia masih tergolong rendah. Rendahnya keterampilan membaca membuktikan bahwa proses pendidikan di Indonesia belum mengembangkan kompetensi dan minat peserta didik terhadap pengetahuan.

Berdasarkan data PIRLS dan PISA di atas, Kementrian Pendidikan dan Kebudayaan mengembangkan Gerakan Literasi Sekolah. Gerakan Literasi Sekolah adalah kemampuan mengakses, memahami, dan menggunakan sesuatu secara cerdas melalui berbagai aktivitas, antara lain membaca, melihat, menyimak, menulis, dan atau berbicara. Disini sekolah diwajibkan meluangkan waktu 15 menit sebelum pembelajaran untuk membaca buku non akademik. Tujuan umum dari gerakan literasi adalah untuk menumbuhkembangkan budi pekerti peserta didik melalui pembudayaan ekosistem literasi sekolah yang diwujudkan dalam Gerakan Literasi Sekolah agar mereka menjadi pembelajar sepanjang hayat (Direktorat Jenderal Pendidikan Dasar Dan Menengah Kementrian Pendidikan dan Kebudayaan, 2016: 2). Gerakan Literasi Sekolah sendiri harus dilaksanakan untuk memperluas ilmu pengetahuan siswa sesuai dengan Peraturan Menteri Nomor 23 Tahun 2015 tentang penumbuhan budi pekerti yang menyebutkan bahwa:

"Penghargaan terhadap keunikan potensi
peserta didik untuk dikembangkan, yaitu
mendorong peserta didik gemar membaca
dan mengembangkan minat yang sesuai
dengan potensi bakatnya untuk memperluas
cakrawala kehidupan di dalam
mengembangkan dirinya sendiri".

Didukung dengan Undang-Undang Republik Indonesia Nomor 20 Tahun 2003 Tentang Sistem Pendidikan Nasional BAB III Pasal 4 Nomor 5 yang tertulis bahwa:

"Pendidikan diselenggarakan dengan
mengembangkan budaya membaca, menulis,
dan berhitung bagi segenap warga
masyarakat".

Salah satu temuan dari penelitian Heather Thomas (2013: 56) menyatakan bahwa program literasi berkontribusi dalam meningkatkan prestasi siswa.

Dalam upaya mensukseskan Gerakan Literasi Sekolah, SD N Tengaran merancang program budaya membaca. Program budaya membaca di SD N Tengaran merupakan suatu program yang dirancang agar siswa saat membaca tidak hanya mahir membaca, akan tetapi siswa dapat memahami isi bacaan. Hal ini sesuai dengan pengertian dari program yaitu serangkaian kegiatan yang dirancang/ direncanakan oleh suatu organisasi, yang dalam pelaksanaannya berlangsung melalui proses yang berkesinambungan (Wirawan, 
2011: 17; Arikunto, 2010: 4; Widoyoko, 2009: 8). Sedangkan pengertian budaya membaca adalah suatu sikap dan tindakan membaca sudah menjadi bagian yang lekat dan mengikat dalam kehidupan sehari-hari seseorang sehingga membaca dilakukan secara teratur dan berkelanjutan (Umar, 2013: 127; Gol A Gong \& Agus M. Irkham, 2012: 62).

Program budaya membaca di SD N Tengaran diputuskan dan dilaksanakan mulai tahun ajaran 2014/2015. Program budaya membaca di sekolah merupakan program yang diharapkan dapat membuat para guru dan seluruh siswa meningkatkan intensitas membaca, sehingga pengetahuan guru dan siswa dapat meningkat. Kepala sekolah, guru dan para siswa diharapkan dapat berperan aktif dalam mengawasi dan melaksanakan program budaya baca. Dalam hal ini SD N Tengaran mewajibkan siswa satu kali dalam satu minggu membuat rangkuman untuk menjadi bukti pemahaman siswa dalam membaca. Hasil rangkuman wajib dikumpulkan ke sekolah melalui guru-guru kelas. Setelah siswa dapat memahami dan mengerti dari isi bacaan tentunya diharapkan pengetahuan dari siswa dapat meningkat, sehingga prestasi dan mutu sekolah dapat meningkat.

Permasalahan yang timbul dalam melaksanakan program budaya membaca yang pertama adalah tentang konsistensi guru-guru. Beberapa guru terkadang malas dalam melaksanakan apa yang menjadi tugas (mengumpulkan hasil rangkuman) dan mengawasi kegiatan program budaya membaca. Hal ini dikarenakan banyaknya tugas dan kegiatan lain para guru di sekolah. Adapun data pengumpulan hasil rangkuman tiga bulan terakhir sebagai berikut:

Tabel 1 Daftar pengumpulan hasil rangkuman pada bulan April - Juni 2016

\begin{tabular}{|c|c|c|c|c|c|c|c|c|}
\hline \multirow{2}{*}{ No } & \multirow{2}{*}{ Kelas } & \multirow{2}{*}{$\begin{array}{c}\text { Jumlah } \\
\text { Siswa }\end{array}$} & \multicolumn{3}{|c|}{$\begin{array}{c}\text { Rangkuman } \\
\text { terkumpul }\end{array}$} & \multicolumn{3}{c|}{$\begin{array}{c}\text { Rangkuman yang } \\
\text { tidak terkumpul }\end{array}$} \\
\cline { 4 - 10 } & & & April & Mei & Juni & April & Mei & Juni \\
\hline 1. & I & 40 siswa & 38 & 40 & 35 & 2 & 0 & 5 \\
\hline 2. & II & 44 siswa & 39 & 36 & 44 & 5 & 9 & 0 \\
\hline 3. & III & 75 siswa & 75 & 70 & 72 & 0 & 5 & 3 \\
\hline 4. & IV & 68 siswa & 66 & 67 & 64 & 2 & 1 & 4 \\
\hline 5. & V & 65 siswa & 60 & 58 & 65 & 5 & 3 & 0 \\
\hline 6. & VI & 64 siswa & 63 & 64 & 64 & 1 & 0 & 0 \\
\hline
\end{tabular}

Sumber: Wawancara tanggal 10 Agustus 2016.

Terlihat dari data di atas selama bulan April, Mei dan Juni 2016 pada kelas 1 terdapat 7 rangkuman yang tidak terkumpul, kelas II terdapat 14 rangkuman yang tidak terkumpul, kelas III terdapat 8 rangkuman yang tidak terkumpul, kelas IV terdapat 7 rangkuman yang tidak terkumpul, kelas $\mathrm{V}$ terdapat 8 rangkuman yang tidak terkumpul, serta pada kelas VI terdapat 1 rangkuman yang tidak terkumpul. Dari tiga bulan terakhir saja terdapat 47 rangkuman yang tidak terkumpul. Hal ini dapat mengakibatkan kelancaran program budaya membaca dapat terganggu 50 sehingga tujuan dari program budaya membaca sangat sulit dicapai. Permasalahan yang kedua yaitu kurangnya pengawasan dari orang tua juga menjadi kendala dalam melaksanakan program budaya membaca. Orang tua lebih fokus kepada pekerjaan dan tidak sempat mengawasi kegiatan belajar anak di rumah. Permasalahan yang terakhir yang muncul adalah kurangnya jumlah buku yang menjadi pembaharuan. Jumlah siswa yang banyak, intensitas membaca yang cepat mengakibatkan perputaran buku dari siswa ke siswa lain juga cepat, sehingga siswa akan 
menjadi bosan dalam membaca jika buku yang dibaca hanya itu-itu saja. Ketiga permasalahan tersebut tidak bisa dianggap remeh, karena permasalahan-permasalahan tersebut dapat menghambat proses kegiatan program budaya membaca dan tujuan akhir dari program budaya membaca yaitu meningkatkan mutu sekolah tidak akan terwujud.

Permasalahan tersebut serupa dengan penelitian yang dilakukan oleh Tahira DuPree Chase (2011: 5) yang berjudul The Children Left Behind: An Evaluation of a Reading Intervention Program for Upper Elementary Students, yang menyatakan bahwa adanya penurunan kemampuan membaca saat siswa memasuki sekolah tingkat menengah. Penelitian tersebut berfokus pada siswa kelas 5 yang menunjukkan kesulitan membaca padahal di sana ada program membaca yaitu program membaca intervensi. Selain itu permasalahan yang dihadapi oleh Heather Thomas (2013) yang berjudul An evaluation of the literacy program at Garibaldi Grade School menyatakan bahwa sejak tahun 2006 sekolah Neah-Kah-Nie sudah mengembangkan program literasi membaca. Guru memanfaatkan model literasi yang seimbang antara teori dan praktek dalam lima bidang utama membaca: fonemik kesadaran, phonics, kelancaran, kosakata, dan pemahaman. Siswa kelas lima dinilai tiga kali dalam setahun menggunakan DIBELS (Dynamic Indicators of Basic Early Literacy Skills), yang dikembangkan oleh University of Oregon. Meskipun sudah dilakukan penilaian secara rutin tetapi masih belum diketahui apakah program literasi efektif meningkatkan kemampuan membaca siswa di sekolah Garibaldi Grade. Penelitian yang dilakukan Corinne Serra Smith, M.S. ED (2009) yang berjudul An Analysis and Evaluation of Sit Stay Read: Is the Program Effective in Improving Student Engagement and Reading Outcomes? menyatakan bahwa program "Sit Stay Read" yang memanfaatkan anjing terapi untuk meningkatkan keterampilan membaca dan menumbuhkan kasih belajar pada anakanak yang kurang beruntung di kelas kedua dan ketiga (usia 7-9) ini efektif dalam meningkatkan kemampuan membaca anak. Akan tetapi belum diketahui apakah program ini meningkatkan prestasi belajar anak-anak di Chicago. Dari beberapa permasalahan tersebut, solusi yang dinilai tepat untuk mengatasi permasalahan permasalahan yang muncul adalah dilakukannya evaluasi suatu program yang berkaitan dengan meningkatkan kemampuan baca anak tersebut.

Dengan berdasar pada uraian tersebut maka penulis tertarik untuk mengadakan penelitian tentang evaluasi program budaya membaca di SD $N$ Tengaran Kabupaten semarang. Pengertian dari evaluasi adalah suatu kegiatan mengumpulkan, menganalisis, dan menyajikan informasi dengan cara membandingkan antara kegiatan yang direncanakan terhadap kegiatan yang dilaksanakan dan membandingkan antara tujuan program terhadap hasil yang tercapai, yang selanjutnya informasi tersebut digunakan untuk mengetahui efektivitas dan efisiensi proyek, kebijakan dan program yang dipakai untuk menentukan alternatif yang tepat dalam mengambil suatu keputusan (Sukardi, 2008: 1); Arikunto, 2010: 2; Wirawan,2011: 7). Sedangkan pengertian dari evaluasi program adalah metode sistematik untuk mengumpulkan, menganalisis, dan memakai informasi dengan tujuan untuk mengetahui efektivitas dan efisiensi proyek, kebijakan dan program (Wirawan,2011: 17; Weiss (Sugiyono, 2014: 741); Sugiyono, 2014: 742). Sementara itu tujuan dari evaluasi program adalah untuk mengetahui apakah tujuan program telah tercapai dan serta mengetahui penyebab-penyebabnya yang selanjutnya hasil evaluasi dapat digunakan untuk mengambil keputusan tentang keberlanjutan sebuah program perlu diteruskan, diperbaiki atau 
dihentikan (Wirawan, 2011: 17; Arikunto, 2010: 18; Endang, 2011: 144-145).

Model yang akan digunakan dalam mengevaluasi program ini adalah CIPP yang dikembangkan oleh Stufflebeam. CIPP singkatan dari context, input, process and product. Tujuan utama penelitian ini adalah untuk memberi masukan untuk perbaikan pelaksanaan program budaya membaca di SDN Tengaran, sehingga dilakukan analisis serta evaluasi tentang program budaya membaca di SD N Tengaran guna mengetahui: 1) Konteks program budaya membaca di SD N Tengaran Kabupaten Semarang; 2) Input program budaya membaca di SD N Tengaran Kabupaten Semarang; Proses program budaya membaca di SD N Tengaran Kabupaten Semarang dan; 4) Produk program budaya membaca di SD N Tengaran Kabupaten Semarang.

Menurut Wirawan (2011: 92-94) model evaluasi CIPP dalam menganalisa program dilaksanakan berdasarkan komponenkomponennya yang dapat dijelaskan sebagai berikut: a) Evaluasi konteks adalah upaya mengidentifikasi dan menilai kebutuhankebutuhan yang mendasari disusunnya suatu program. Evaluasi konteks untuk menjawab pertanyaan: Apa yang perlu dilakukan?(What needs to be done?). b) Evaluasi Masukan (input) untuk mencari jawaban atas pertanyaan: Apa yang harus dilakukan? (What should be done?). Evaluasi ini mengidentifikasi problem, asset dan peluang untuk membantu para pengambil keputusan mengidentifikasi tujuan, prioritas, dan manfaat-manfaat dari program, menilai pendekatan alternatif, rencana tindakan, rencana staf dan anggaran untuk feasibilitas dan potensi cost effectiveness untuk memenuhi kebutuhan dan tujuan yang ditargetkan. Para pengambil keputusan memakai evaluasi pekerjaan, menilai rencana-rencana aktivitas, dan penganggaran. 3) Evaluasi Proses berupaya untuk mencari jawaban atas pertanyaan dari: Apakah program sedang dilaksanakan? (Is it being done?). Evaluasi ini berupaya mengakses pelaksanaan dari rencana untuk membantu staf program melaksanakan aktivitas dan kemudian membantu kelompok pemakai lebih luas menilai program dan menginterpretasikan manfaat. 4) Evaluasi produk diarahkan untuk mencari jawaban pertanyaan: Did it succed?. Evaluasi ini berupaya mengidentifikasi dan mengakses keluaran dan manfaat, baik yang direncanakan atau tidak direncanakan, baik jangka pendek maupun jangka panjang. Evaluasi produk merupakan tahap akhir dari serangkaian evaluasi program. Jadi setelah evaluasi produk selesai dapat direkomendasikan hasil program yang berjalan untuk merumuskan kebijakan berikutnya.

\section{METODE PENELITIAN}

Jenis penelitian ini merupakan penelitian evaluatif menggunakan pendekatan deskriptif kualitatif. Tempat penelitian di SD $\mathrm{N}$ Tengaran Kecamatan Tengaran Kabupaten Semarang Provinsi Jawa Tengah. Subyek dalam penelitian ini adalah Kepala Sekolah, pendidik, dan peserta didik SD N Tengaran. Teknik pengumpulan data menggunakan wawancara, observasi dan studi dokumen. Instrumen pengumpulan data berupa lembar wawancara, lembar observasi dan lembar dokumentasi. Untuk menguji keabsahan data pada penelitian ini digunakan teknik triangulasi sumber dan tringulasi teknik. Teknik analisis data yang digunakan adalah analisa data kualitatif. Analisa data di dalam penelitian kualitatif ini didasarkan pada metode evaluasi program dengan model CIPP.

\section{HASIL PENELITIAN PEMBAHASAN} masukan dalam memilih rencana-rencana yang ada, menyusun proposal pendanaan, alokasi sumber-sumber, menetapkan staf, menskedul

DAN 
Konteks Program Budaya Membaca di SD N Tengaran Kabupaten Semarang

Komponen pada evaluasi konteks adalah: 1) apakah program budaya membaca merupakan kebutuhan sekolah; 2) apa tujuan dari program budaya membaca serta; 3) siapa sasaran dari program budaya membaca. Latar belakang dirancangnya program budaya membaca di SD N Tengaran adalah Kepala Sekolah melihat bahwa kemampuan baca tulis siswa masih kurang, yaitu ada beberapa siswa kelas 1, 2, 3 bahkan kelas 5 belum lancar membaca. Hal ini terlihat ketika salah satu siswa kelas 5 diberi tugas untuk membacakan UUD 1945 ketika Upacara Bendera hari senin namun siswa tersebut belum lancar membaca. Permasalahan ini serupa dengan penelitian yang dilakukan oleh Nurfalah (2015) yang menyatakan bahwa siswa kelas II di SDN 1 Wosu Kecamatan Bungku Barat Kabupaten Morowali belum lancar membaca, serta penelitian yang dilakukan oleh Sukartiningsih (2005) yang menemukan bahwa siswa kelas I SD N Arjosari 1 belum lancar membaca dan menulis.

Untuk mengatasi permasalahan rendahnya kemampuan membaca siswa SD N Tengaran pihak sekolah merancang program budaya membaca. Melalui program ini diharapkan kegiatan membaca menjadi kebiasaan bagi siswa selanjutnya kemampuan membaca siswa meningkat. Hal ini sesuai dengan pengertian program menurut Widoyoko (2009: 8) yaitu serangkaian kegiatan yang direncanakan dengan seksama dan dalam pelaksanaannya berlangsung dalam proses yang berkesinambungan, dan terjadi dalam suatu organisasi yang melibatkan orang banyak. Berdasarkan permasalahan tersebut dapat diketahui bahwa program budaya membaca merupakan kebutuhan siswa SD N Tengaran. Hal ini senada dengan pengertian kebutuhan menurut Wirawan (2011: 19) yaitu ketimpangan antara kondisi dan keadaan sekarang atau apa yang terjadi dengan keadaan yang diinginkan atau keadaan yang seharusnya.

Tujuan dari program budaya membaca di SD N Tengaran adalah untuk melatih keterampilan membaca dan menulis, khususnya meningkatkan literasi bagi siswa. Hal ini sesuai dengan tujuan Gerakan Literasi Sekolah yaitu untuk menumbuhkembangkan budi pekerti peserta didik melalui pembudayaan ekosistem literasi sekolah yang diwujudkan dalam Gerakan Literasi Sekolah agar mereka menjadi pembelajar sepanjang hayat (Direktorat Jenderal Pendidikan Dasar Dan Menengah Kementrian Pendidikan dan Kebudayaan, 2016: 2). Program budaya membaca sendiri sangat penting bagi siswa SD $\mathrm{N}$ Tengaran karena dengan adanya program budaya membaca siswa akan mempunyai wawasan yang lebih luas, serta program ini dapat membantu siswa dalam mengikuti proses pembelajaran dan pengembangan diri. Hal ini serupa dengan hasil penelitian yang dilakukan oleh Heather Thomas (2013: 56) menyatakan bahwa program literasi berkontribusi dalam meningkatkan prestasi siswa.

\section{Input Program Budaya Membaca di SD N Tengaran Kabupaten Semarang}

Program budaya membaca merupakan jawaban dari permasalahan dari rendahnya kemampuan membaca siswa SD N Tengaran. Hal ini sesuai dengan pendapat dari Wirawan (2011: 19) yang menyatakan bahwa assesmen kebutuhan perlu dilakukan sebelum merencanakan suatu kebijakan, program atau proyek. Hal ini dilakukan untuk mengidentifikasi dan mendefinisikan kebutuhan dan mengumpulkan sejumlah alternatif untuk memenuhi kebutuhan tersebut. Dari alternatif yang dipilih merupakan inti dari rencana program untuk memenuhi kebutuhan.

Program budaya membaca di SD N Tengaran sudah sesuai dengan juklak dan juknis yang dibuktikan dengan 7 kegiatan 
program yaitu membaca 5 menit sebelum PBM, membaca massal, membuat mading, cipta baca puisi, membuat pidato, merangkum hasil bacaan dan menulis buku harian (Diary). Tiga kegiatan bersifat rutin (membaca 15 menit sebelum PBM, merangkum hasil bacaan dan menulis buku harian (Diary)) serta empat kegiatan yang dilakukan ketika jeda semester (membaca massal, membuat mading, cipta baca puisi, membuat pidato), namun terkhusus untuk kegiatan cipta baca puisi dan membuat pidato sering dipersiapkan untuk mengikuti perlombaan.

Program hanya bisa berjalan komponen pendukung berfungsi sebagaimana mestinya, adapun komponen pendukung meliputi: 1) Sumber daya manusia; 2) Sarana prasarana pendukung; 3) Dana/anggaran; 4) Berbagai prosedur dan aturan yang diperlukan. Oleh karena itu dapat diketahui sumber daya pendukung program budaya membaca di sekolah ini dari visi dan misi serta tujuan sekolah. Karakteristik pemimpin, guru dan warga sekolah harus melingkupi visi dan misi serta tujuan sekolah.

Kepala Sekolah mempunyai tanggung jawab yang besar terhadap pelaksanaan program budaya membaca. Kemampuan manajemen Kepala Sekolah dalam menjalankan program budaya membaca ini berpengaruh dalam pelaksanaan program. Kebijakan dan keputusan yang diambil Kepala Sekolah dalam mengatasi kendala yang muncul pada saat proses pelaksanaan program budaya membaca sangat menentukan keberhasilan program tersebut. Kemampuan Kepala Sekolah dalam bekerja sama dengan guru dapat melancarkan pelaksanaan sehingga tidak muncul masalah dalam melaksanakan kegiatan program budaya membaca di SD N Tengaran. Guru sebagai SDM juga mempunyai peranan yang besar dalam mensukseskan kegiatan program budaya membaca. Untuk itu guru mendapatkan pelatihan dari Sekolah berupa supervisi guru, selain itu guru juga mendapatkan pelatihan dari USAID PRIORITAS mengenai budaya membaca, guna mempersiapkan diri untuk melaksanakan kegiatan-kegiatan pada program budaya membaca. Berdasarkan uraian tersebut dapat diketahui bahwa SDM sudah memadahi untuk menunjang kegiatan program budaya membaca.

Selain kredibilitas pengelola, pelaksanaan program budaya membaca di SD $\mathrm{N}$ Tengaran harus didukung keuangan sekolah. Besaran dana yang dialokasikan untuk pelaksanaan kegiatan program budaya membaca di SD N Tengaran yang tercantum dalam RKAS sebesar 5\% dari penerimaan dana BOS pertahunnya. Besaran dana tersebut dinilai sudah memadahi untuk menunjang kegiatan budaya membaca di SD N Tengaran. Pengadaan sarana prasarana juga sebagai input pelaksanaan program budaya membaca di SD $\mathrm{N}$ Tengaran juga sudah memadahi. Adapun sarana prasarana yang dipersiapkan antara lain adalah, buku, ruang baca, teras baca (pralon baca), sudut baca (didalam kelas), taman baca (gazebo) serta peralatan lain yang mendukung terlaksananya program tersebut. Dengan adanya dukungan peralatan tersebut pelaksanaan program menjadi lancar serta tidak ada kendala.

Aturan-aturan juga dibuat untuk mensukseskan kegiatan program budaya membaca. Selain itu jadwal yang baik membuat peminjaman buku berlangsung secara teratur. Jadwal serta aturan dipajang pada tempat-tempat yang strategis supaya siswa dengan mudah membaca serta memahami kegiatan-kegiatan program budaya membaca dengan mudah. Penerapan pelaksanaan program budaya membaca mendapat dukungan dari beberapa pihak antara lain, warga sekolah, komite sekolah, serta orang tua murid. Pihak sekolah memiliki kapasitas yang tinggi sebagai perencana dan pelaksana program budaya membaca. Hal ini 
berkaitan dengan keberhasilan pelaksanaan program budaya membaca.

\section{Proses Program Budaya Membaca di SD N Tengaran Kabupaten Semarang}

Pada tahun ajaran 2014/2015 program budaya membaca mulai dilaksanakan. Hal ini sebagai tindak lanjut dari kerjasama pihak sekolah dengan USAID PRIORITAS. Pada tahap awal pelaksanaan program budaya membaca SD N Tengaran membentuk panitia literasi, yang selanjutnya menyusun rencana program budaya membaca, kemudian dimusyawarahkan kepada seluruh guru dalam rapat kerja tahunan, dan akhirnya disosialisasikan kepada seluruh warga sekolah termasuk orangtua siswa. Rencana anggaran biaya untuk koleksi buku dan fasilitas untuk membaca harus disediakan. Dalam rencana anggaran tersebut diuraikan jenis-jenis fasilitas yaitu, ruang baca, sudut baca, teras baca serta taman baca.

Pada dasarnya evaluasi proses untuk mengetahui sampai sejauh mana rencana telah diterapkan dan komponen apa yang perlu diperbaiki. Dimulai dari peran guru dalam melaksanakan kegiatan program budaya membaca di sekolah sangatlah dibutuhkan agar nantinya siswa benar-benar paham dan mengaplikasikan dalam kehidupan sehari-hari. Hal ini sesuai dengan temuan pada penelitian yang dilakukan oleh Heather Thomas (2013), bahwa guru merupakan komponen yang sangat mendukung peningkatan kemampuan membaca siswa terutama pada program literasi.

Namun kendala yang di hadapi oleh SD $\mathrm{N}$ Tengaran adalah kurangnya komitmen guru dalam melaksanakan kegiatan-kegiatan program budaya membaca, terutama pada kegiatan yang bersifat rutinitas yaitu pada kegiatan membaca 15 menit sebelum PBM dan kegiatan merangkum. Pada kegiatan membaca 15 menit sebelum PBM belum berjalan sesuai dengan jadwal, kendala yang dihadapi adalah beberapa guru belum hadir saat kegiatan berlangsung sehingga banyak kelas yang tidak tertunggui, akibatnya kegiatan membaca 15 menit sebelum PBM terhambat pada pelaksanaannya. Untuk mengatasi hal tersebut dari pihak sekolah sudah melakukan berbagai solusi antara lain adalah Kepala Sekolah memberikan motivasi kepada guru-guru agar mempunyai komitmen yang tinggi dalam melaksanakan kegiatan membaca 15 menit sebelum PBM. Selain itu guru lain yang sudah hadir sebelum kegiatan berlangsung dimintai tolong untuk menghendel kelas-kelas yang belum tertunggui oleh guru kelas.

Pada kegiatan merangkum selain konsistensi guru-guru yang lemah, pengawasan orangtua yang kurang juga menjadi kendala. Beberapa anak tidak melaksanakan kegiatan ini. Hal ini dikarenakan kegiatan merangkum dilaksanakan dirumah siswa, sehingga peran orangtua menjadi sangat krusial dalam melancarkan kegiatan merangkum. Solusi yang sudah dilakukan pihak sekolah adalah guru harus senantiasa bekerja sama dengan pihak orangtua untuk selalu mengawasi kegiatan belajar siswa ketika dirumah.

Berdasarkan hasil temuan di lapangan dan kajian dokuman diperoleh informasi bahwa pada aspek proses pelaksanaan program budaya membaca di SD N Tengaran belum sepenuhnya terlaksana dengan baik. Namun kendala-kendala yang muncul pada tahap proses teratasi dengan baik. Hal ini karena adanya kerja sama yang baik dengan berbagai pihak yang terlibat dalam proses pelaksanaan program budaya membaca.

\section{Produk Program Budaya Membaca di SD N Tengaran Kabupaten Semarang}

Evaluasi produk merupakan penilaian yang dilakukan guna untuk melihat ketercapaian/ keberhasilan suatu program dalam mencapai tujuan yang ditentukan sebelumnya. Hasil yang didapatkan dari 
evaluasi produk adalah keuntungan pelaksanaan program budaya membaca di SD $\mathrm{N}$ Tengaran. Siswa mampu untuk membaca dan menulis secara lancar sehingga mampu membantu siswa dalam meningkatkan prestasi belajar.

Dari ketujuh kegiatan program budaya membaca terdapat lima kegiatan dengan ukuran keberhasilan baru pada tingkat keterlibatan siswa, dan ukuran kualitas belum dimasukkan, yaitu 15 menit sebelum PBM terdapat $90 \%$ siswa SD N Tengaran mampu lancar membaca, 60\% siswa SD N Tengaran berani presentasi, $66 \%$ siswa mampu membuat pidato secara mandiri, 66\% siswa mampu membuat merangkum hasil bacaan secara mandiri, serta $90 \%$ siswa aktif menulis buku harian (Diary). Sedangkan untuk dua kegiatan lain yaitu kegiatan cipta baca puisi dan membuat pidato ukuran kualitas bagi tingkat keberhasilan sudah dimasukkan. Untuk kegiatan cipta baca puisi dari kelas 5 dan 6 yang dipersiapkan, kemudian diseleksi untuk diperlombakan, satu anak lolos seleksi tingkat Kecamatan untuk lomba membaca puisi ketingkat Kabupaten. Sedangkan untuk kegiatan membuat pidato dari 65 siswa yang dipersiapkan, setelah melalui seleksi, terdapat satu anak yang mendapat peringkat 3 pada tingkat kecamatan.

Produk berupa hasil karya siswa adalah hasil rangkuman (resume), buku harian (diary), puisi, naskah pidato sederhana serta karya-karya yang dipajang pada majalah dinding (mading) juga merupakan ciri utama keberhasilan pelaksanaan program budaya membaca di SD N Tengaran. Keberhasilan pelaksanaan program budaya membaca dapat dilihat juga dari prestasi siswa SD N Tengaran yang mampu menjuarai perlombaan membaca pidato dan lomba membaca puisi tingkat kecamatan, serta meningkatnya nilai siswa pada mata pelajaran bahasa Indonesia. Selain itu bertambahnya koleksi buku, terciptanya taman baca, sudut baca, teras baca serta ruang baca yang memadai, kondusif dan menyenangkan. Berdasarkan uraian di atas dapat disimpulkan bahwa pelaksanaan program budaya membaca di SD N Tengaran Kabupaten Semarang menghasilkan produk yang sesuai dengan yang diharapkan. Dampak positif dari pelaksanaan program budaya membaca adalah meningkatnya kemampuan dan minat membaca siswa SD N Tengaran Kabupaten Semarang. Hal ini sesuai dengan penelitian terdahulu yang dilakukan oleh Syarifatul Fitria dan Suparno (2016), bahwa dengan adanya pembelajaran keterampilan membaca permulaan, kemampuan membaca siswa TK Fastrack Fun School Kelas A berkembang sesuai dengan harapan. Hasil yang berbeda pada penelitian yang dilakukan oleh James D. Quinn (2014), bahwa model "Read to Learn" secara statistik tidak memberikan dampak pada kelancaran maupun pencapaian dalam membaca.

\section{SIMPULAN DAN SARAN}

\section{Simpulan}

Pada aspek konteks, program budaya membaca sangat dibutuhkan siswa di SD N Tengaran. Adapun sasaran program budaya membaca adalah seluruh warga sekolah khususnya siswa. Tujuan dari program budaya membaca adalah untuk melatih keterampilan membaca dan menulis, khususnya meningkatkan literasi bagi siswa. Pada aspek input, program budaya membaca di SD N Tengaran sudah menjawab kebutuhan sekolah dengan ditopang kegiatan, SDM, sarana dan prasarana, dana serta mekanisme kerja yang memadai. Pada aspek proses pelaksanaan program budaya membaca berjalan lancar meski terdapat beberapa kendala kendala. Serta pada aspek produk program budaya membaca telah tercapai sesuai dengan rencana awal, walaupun tingkat keberhasilan pada lima kegiatan masih pada tingkat keterlibatan siswa diantaranya: kegiatan membaca 15 sebelum PBM, merangkum, menulis buku harian 
(diary), membaca masal dan membuat mading, sedangkan dua yang lain sudah pada tingkat kualitas, yaitu kegiatan cipta baca puisi dan membaca pidato.

\section{Saran}

Saran yang bisa diberikan berdasarkan simpulan diatas adalah:

1. Bagi Kepala Sekolah

Kepala Sekolah hendaknya menambah pelatihan-pelatihan yang berkaitan dengan program budaya membaca, agar motivasi guru meningkat sehingga program budaya membaca dapat dilanjutkan dan berjalan sesuai dengan rencana.

2. Bagi Tim Literasi SD N Tengaran

a. Tim literasi sekolah hendaknya meningkatkan kualitas produk dari setiap kegiatan dengan menetapkan kriteria penilaian yang jelas.

b. Tim literasi hendaknya menambah kegiatan-kegiatan baru yang sesuai, untuk mengembangkan program budaya membaca.

3. Bagi Guru SD N Tengaran

Guru hendaknya senantiasa bekerja sama dengan orangtua siswa agar meluangkan waktu untuk mengawasi anak-anaknya ketika belajar disekolah maupun dirumah.

4. Bagi sekolah lain

Sekolah-sekolah yang melaksanakan program yang serupa, hendaknya selalu mengevaluasi program secara mendalam setidaknya satu atau dua tahun sekali agar program yang sudah berjalan dapat dilanjutkan sesuai dengan perencanaan.

\section{DAFTAR PUSTAKA}

Arikunto, Suharsimi dan Jabar, epi Safruddin Abdul. 2010. EVALUASI PROGRAM PENDIDIKAN: Pedoman Teoretis Praktis Bagi Mahasiswa dan Praktisi Pendidikan. Edisi Kedua, Cetakan ke empat, Jakarta: Bumi Aksara.
Corinne Serra Smith, M.S. ED. 2009. An Analysis and Evaluation of Sit Stay Read: Is the Program Effective in Improving Student Engagement and Reading Outcomes?. Dissertations. National-Louis University.

Direktorat Jenderal Pendidikan Dasar Dan Menengah Kementerian Pendidikan Dan Kebudayaan. 2016. Panduan Gerakan Literasi Sekolah Di Sekolah Sekolah Dasar. Jakarta: Bagian Perencanaan dan Penganggaran Sekretariat Direktorat Jenderal Pendidikan Dasar dan Menengah.

Endang Mulyaningsih. 2011. Riset Terapan Bidang Pendidikan dan Teknik. Yogyakarta: UNY Pres.

Fitria, Syarifatul \& Suparno, 2016. Evaluasi Pembelajaran Keterampilan Membaca Permulaan Di Tk Fastrack Funschool Kelas A Program Nusantara Yogyakarta. jurnal Pendidikan dan Pemberdayaan Masyarakat Volume 3 Nomor 1, Maret 2016, (85 - 96).

Gol A Gong \& Agus M. Irkham. 2012. Gempa Literasi. Dari Kampung Untuk Nusantara. Jakarta: PT Gramedia.

Heather Thomas. 2013. An evaluation of the literacy program at GaribaldiGrade School. Doctor of Education. George Fox University.

James D. Quinn. 2014. A Program Evaluation of the Impact of a "Read to Learn" Model on Alternative High School Students' Lexile Levels and Reading Achievements. A Dissertation Submitted to the Gardner-Webb University School of Education.

Nurfalah, 2015. Upaya Meningkatkan Kemampuan Membaca Permulaan Melalui Pendekatan Proses pada Siswa Kelas II SDN 1 Wosu Kec. Bungku 
Barat Kab. Morowali. Jurnal Kreatif Tadulako Online Vol. 3 No. 1 ISSN 2354-614X.

OECD. (2015). PISA 2015 Results in Focus. Programme for International Student Assessment, $1-16$. https://www.oecd.org/pisa/pisa-2015results-in-focus.pdf

Peraturan Menteri Nomor 23 Tahun 2015 Tentang Penumbuhan Budi Pekerti.

Sugiyono, 2014. Metode Penelitian Manajemen, Bandung: CV. Alfabeta.

Sukardi, 2008. EVALUASI PENDIDIKAN: Prinsip \& Operasionalnya. Jakarta: Bumi Aksara.

Sukartiningsih, Wahyu, 2005. Peningkatan Kemampuan Membaca Dan Menulis Permulaan Melalui Pembelajaran Konstruktivisme. JURNAL PENDIDIKAN DASAR, VOL.6 NO.2. Program PGSD FIP Universitas Negeri Surabaya.

Tahira DuPree Chase. 2011. The Children Left Behind: An Evaluation of a Reading Intervention Program for Upper Elementary Students. Education Doctoral. St. John Fisher College.

Umar, Touku. 2013. Perpustakaan sekolah dalam menanamkan budaya membaca. Jurnal: UIN Alauddin, Gowa.

Undang-Undang Republik Indonesia Nomor 20 Tahun 2003 Tentang Sistem Pendidikan Nasional BAB III Pasal 4 Nomor 5.

Widoyoko, Eko Putro. 2009. EVALUASI PROGRAM PEMBELAJARAN: Panduan Praktis Bagi Pendidik dan Calon Pendidik. Yogyakarta: Pustaka Belajar.
Wirawan, 2011. EVALUASI: Teori, Model, Standar, Aplikasi, dan Profesi. Jakarta: Rajawali Pers. 